\begin{tabular}{|l|}
\hline 資 料 \\
\hline
\end{tabular}

韓国の獣医学教育

〜特に解剖学教育について〜

李 興 植 (ソウル国立大学校獣医解剖学教授)

まず，韓国には以下のように国立 9 校，私立 1 校の計 10 校の獣医大学校がある.

韓国の獣医大学校 $<(\quad$ ）内は創立年 $>$

国立：ソウル大学校（1947）, 全北大学校 (1951), 全南大学校 (1952), 慶北大学校 (1953), 慶尚大学校（1955）, 忠南大学校 (1982), 江原大学校 (1988), 忠北大学校 (1989), 済州大学校 (1989)

私立：建国大学校（1968）

各大学の 1996 年における解剖学教官数と学生数は表 1 のとおりである.

学生定員は 40 から 69 名で男女学生の比率は 6:4 程 度. 教授と学生の比率は平均 $1: 29$ であり, これは世界 29 力国 33 校を対象としてフランスのッールーズ獣医科 大学のリ又レ教授が調査・報告した世界平均 $1: 30$ に近 くなっている.

現在の 4 年制の課程は, 1 年生が教養課程， 2 年生が 基礎獣医学， 3 年生が前臨床課程，および，4 年生が臨 床医学課程となっている。このうち獣医解剖学教育は, 10 大学の内, 8 つの大学が 2 年生の前期と後期に分けて 16 週ずつ全部で 32 週間教育が行われている。また，の こりの 2 つの大学では， 1 年生の後期と 2 年生の前・後 期に合計，48 週にわたって肉眼解剖学の教育が行われ ている.

現在, 韓国で教育している形態学分野の講義時間は約 202 時間，実習は 263 時間である.

韓国で肉眼解剖学の教育は犬を基本動物として, 牛,

表 1 各大学の解剖学教官数と学生数 (1996)

\begin{tabular}{|c|c|c|}
\hline 大 学 & 解剖学教官 & 学生(男/女) \\
\hline ソウル & 3 & $69(56 / 13)$ \\
\hline 全 北 & 2 & $57(31 / 26)$ \\
\hline 全＼cjkstart南 & 2 & $54(25 / 29)$ \\
\hline 慶 北 & 2 & $51(21 / 30)$ \\
\hline 慶＼cjkstart尚 & 2 & $57(31 / 26)$ \\
\hline 忠 南 & 2 & $65(38 / 27)$ \\
\hline 江＼cjkstart原 & 1 & $40(26 / 14)$ \\
\hline 忠 北 & 2 & $40(25 / 15)$ \\
\hline 済 州 & 1 & $45(30 / 15)$ \\
\hline 建＼cjkstart国 & 1 & $50(28 / 22)$ \\
\hline 計 & 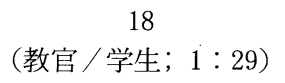 & $\begin{array}{l}528(311 / 217) \\
\text { (男/女；6：4) }\end{array}$ \\
\hline
\end{tabular}

馬, 豚, 山羊などの比較解剖学の教育が行われている (表 2 ).

しかし，これらは学校事情によって差があり，実際に 犬は学生 5 名に 1 頭, 牛は 75 名に 1 頭, 山羊は 14 名に 1 頭のこともあり, また, 大学の事情によって, 犬が学 生 2 名に 1 頭, 牛は 30 名に 1 頭ということあある.

獣医解剖の成績の評価は平均的に中間試験 20\%, 期 末試験 26.6\%, 実習試験 15\%, 随時試験 12.5\%, 口頭 試問 $11.6 \%$ ，などになっている。 また, 大学によって随 時試験 $80 \%$ と口頭試問 20\%だけで評価することもある.

各大学には大学院が設置されているが，その目的とし て挙げられているのは以下のようなことである.

(1)教育と研究を連帯 $(86.5 \%)$, (2)教育レベルの向上 (74.4\%)，(3)新しい技術の応用および開発 $(67.4 \%)$, (4) 学者の養成 (51.0\%), (5)学部教育の支援 (40.5\%)

現在の大学院生在籍者数と, これまで 20 年間に学位 を取得した者の数は表 3 のごとくである.

現在，博士学位を取得した者の $8 \%$ がポストドクトラ ル, $20 \%$ が大学教官， $17 \%$ が公務員， $45 \%$ が研究所研究

表 2

\begin{tabular}{ccc}
\hline \hline 献 体 & 適正学生数勧告案 & 韓国獣医解剖学会による調查 \\
\hline 犬 & 4 & 3 \\
牛 & 20 & 20 \\
山羊/羊 & 4 & 40 \\
豚 & 10 & 30 \\
鶏 & 1 & 3 \\
馬 & 50 & 25 \\
\hline
\end{tabular}

表 3 大学別大学院生数

\begin{tabular}{ccccccc}
\hline \hline \multirow{2}{*}{} & \multicolumn{2}{c}{ 在 } & 籍 & 者 & & \multicolumn{2}{c}{ 学位取得者 } \\
\cline { 2 - 3 } \cline { 5 - 6 } & 修 士 & 博 士 & & 修 士 & 博 士 \\
\hline ソウル大学校 & 3 & 4 & & 25 & 12 \\
全北大学校 & 2 & 1 & & 8 & 2 \\
全南大学校 & 4 & 1 & & 5 & 1 \\
慶北大学校 & 2 & 1 & & 4 & 2 \\
慶尚大学校 & 1 & - & & 16 & 3 \\
忠南大学校 & 5 & 3 & & 0 & 1 \\
江原大学校 & 1 & - & & 1 & - \\
忠北大学校 & 9 & 2 & & 2 & - \\
済州大学校 & 4 & 1 & & - & - \\
建国大学校 & 3 & 1 & & 1 & - \\
\hline 計 & 34 & 14 & 62 & 21 \\
\hline
\end{tabular}


表 4 学位取得者の就業分野

\begin{tabular}{lcc}
\hline \hline & 修士課程(\%) & 博士課程(\%) \\
\hline 進 学 & 31 & 8 \\
大学教官 & 4 & 20 \\
公 務 員 & 7 & 17 \\
民間企業 & 21 & 8 \\
研 究 所 & 27 & 37 \\
開業獣医師 & 7 & 3 \\
そ の 他 & 3 & 7 \\
\hline & 100 & 100
\end{tabular}

員である（表 4 ）.

韓国は来年（1998 年）から6 年制の獣医学教育を始 めるが，その理由には次のような状況がある.

(1)コンパニオンアニマル, 野生動物, 動物園動物, 水 棲動物, 実験動物など, 獣医学の対象動物の多様化 (2)公害防止之管理目的の環境分野, 新薬開発の医薬分

野, 衛生的に安全な食品供給の食品分野など, 職域 の拡大

(3)WTOによって畜産物の輸出入が自由化

(4)遺伝育種のための核移植, 核置換などのライフサイ エンスの発展

(5)老齢人口，核家族化，独身の急激な増加および，所 得の増加による社会経済的な需要の変化

6 年制教育によって韓国の 21 世紀の獣医師は, 最高 の医療施術者, 賢明な意思決定者, 尊敬される指導者, 明晰な経営管理者, 有能な科学者になると期待されてい る.

現在，韓国は 21 世紀に向かって，教育改革を進めて いるが，その方向を定める原則は以下の 4 点である.

(1)今までの一定期間に一定の大学しか教育が受けられ なかった閉鎖システムから，どの大学でも，いっで あ教育が受けられる開放教育システムへの転換.

(2)教官が主体である教育から, 学生中心教育への転換. (3)画一的教育から，地域状況とか社会要求にあう多様 な教育への転換.

(4)中央政府の管理する教育から，個性を大事にする自 立教育への転換.

6 年制獣医学教育の課程は予科 2 年，本科 4 年からな り，予科 1,2 年生は教養課程である。本科 1,2 年生は 基礎獣医課程, 3 年生は基礎臨床獣医学々臨床獣医学の 課程であり，また 4 年生は臨床獣医学の選択課程である.

ここで韓国の獣医師の立場を国際的に比較してみると 韓国では開業獣医師は $29 \%$ にすぎないとが特徵であ る（表 5,6).

現在の韓国の科学技術レベル，特に獣医学と関係ある 生命工学技術, 食品, 医薬品の毒性および安全性試験レ ベルは，先進国に比べると，40～50\%であるが，2005〜 2010 年までには先進国のレベルまで向上させようと思
表 51994 年の韓国の獣医師数, 家畜単位, 肉生産量, 乳生産量と GNP の国際比較

\begin{tabular}{lccccc}
\hline & アメリカ & 日本 & ドイッ & フランス & 韓国 \\
\hline 家畜単位 $\left(10^{6}\right)$ & 117 & 10 & 24 & 26 & 5 \\
獣医師数 $\left(10^{3}\right)$ & 56 & 28 & 17 & 10 & 6 \\
$\begin{array}{l}\text { 獣医師当たり家畜 } \\
\text { 単位 }\left(10^{3}\right)\end{array}$ & 2.1 & 0.3 & 1.3 & 3.7 & 0.8 \\
$\begin{array}{l}\text { 獣医師当たり肉の } \\
\text { 生産高 }\left(10^{3} \mathrm{~m} / \mathrm{t}\right)\end{array}$ & 0.34 & 0.08 & 0.30 & 0.15 & 0.09 \\
$\begin{array}{l}\text { 獣医師当たり乳の } \\
\text { 生産高 }\left(\mathrm{m} / \mathrm{t} 10^{3}\right)\end{array}$ & 1.24 & 0.43 & 1.64 & 2.53 & 0.33 \\
$\mathrm{GNP}\left(\mathrm{us} \$ 10^{3}\right)$ & 25.8 & 37.0 & 22.3 & 25.7 & 8.6 \\
\hline
\end{tabular}

\begin{tabular}{|c|c|c|c|c|}
\hline & 公務員 & 大学・研究所 & 開業獣医師 & その他 \\
\hline アメリカ & 6 & 9 & 70 & 15 \\
\hline 日 本 & 29 & 5 & 55 & 11 \\
\hline ドイッ & 11 & 14 & 49 & 26 \\
\hline フランス & 5 & 9 & 77 & 9 \\
\hline 韓国 & 22 & 3 & 29 & 46 \\
\hline
\end{tabular}

っている.

明年度から予定される 6 年制カリキュラムでの科目は 1,2 年生 (予科) では次のようなむのが勧告されてい る.

細胞生物学, 統計学, 国語, 社会学, 獣医英語, 獣医 情報科学, 遺伝学, 化学, 生化学, 分子生物学, 獣医 倫理学, 外国語, 経済学, 動物行動学, 獣医学史, 物 理学, 生物学, コンピューターサイエンス

前臨床課程では次の科目が予定されている.

獣医遺伝学, 生物工学, 細胞生物学, 神経科学, 医学 統計学, 神経解剖学, 分子生物学

基礎獣医学課程では次のような科目を予定している. 環境医学, 動物福祉, 獣医経済学, 野生動物保護学, 魚病学, 伝染病学, 獣医倫理学, 野生動物保護, 動物 生態学, 機器分析

専門 4 年生の臨床課程で予定される科目は以下のとお りである。

家族計画, 獣医眼科学, 獣医小児科学, 獣医看護学, 病院管理学, 歯科, 皮膚科, 老人医学, 救急医学, イ メージング解析

選択科目として予定されているあのは次のような科目 である。

馬学, 狩猟動物医学, 動物行動学, 臨床薬理学, 獣医 針診療, 水棲動物医学, 爬虫類医学, 臨㦿解剖学, 獣 医腫瘍学, 獣医内分泌学

形態学と関連がある新しい教科目としては, 細胞生物 学, 分子生物学, 獣医遺伝学, 神経科学, 春椎動物解剖 学, 動物生態学, 神経解剖学, 臨床解剖学などが予定さ れている.

いっぽう，これらの教育を効率的にするためには教科 
方法の改善屯必要であり，既述の上うに，(1)教育者中心 教育加ら学生中心教育への転換，(2)教科目中心加ら総合 講義，講義中心教育加ら問題中心学習への転換，(3)必修 科目は減らして選択教育機会を拡人などの縱断的, 横断 的な教育方針が提示されている。

問題中心学習 (Problem Based Learning) というこ とは問题解決能力を育成する基木教育である。獣医学教 育終了後の獣医師はいつも一人で決定して行動しなけれ ばならず，患音の手術や臨床検査の項目などを自分で判 断して決定しなければならないので，この教育方法は非 常に有用なむのとして評価されている。

総合講義は一つの主題を同じ目的として, 縱断的・横

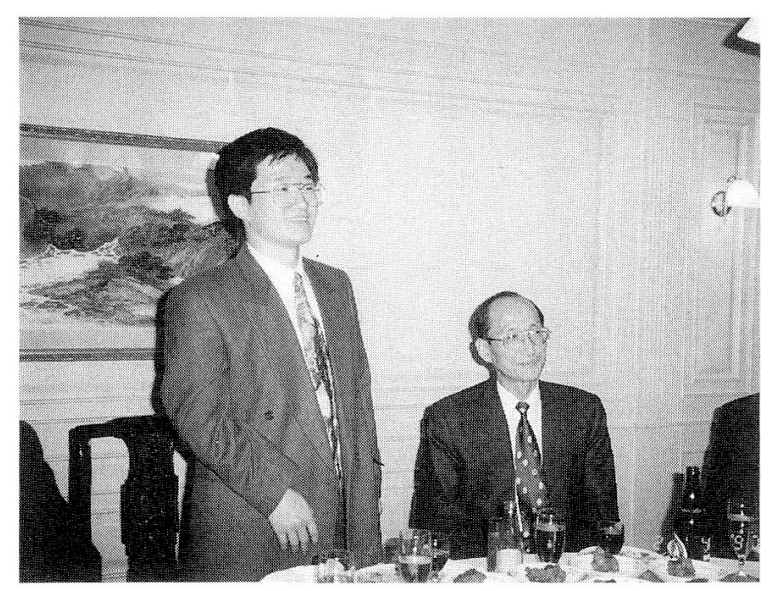

写真はパーティーでの李教授之南氏.
断的な講義を同時に実施する教育である。これは，学生 に学習動機を与えて, 興味を誘発させる教育方法として 提案されている.

以上，韓国での獣医解剖学教育の現状上展望について 概括的に述べた。韓国は来年から始まる 6 年制獣医学教 育で獣医学発展に大きな転機を迎える，成功可否は数年 後にわかると思うが，先に 6 年制を始めた日本の経験に 基づく協力を求願いしたい。

(附記)

本稿は平成 9 年 4 月 2 日, 獣医解剖学会主催の講演会 でッウル大学校 李與植教授が東大家畜解剖学教室に留 学中の南相充氏の通訳で約一時間半にわたって韓国の獣 医学教育について述べられたものをもとによりまとめた あのである。な打紙数の都合で講演原稿の約 $2 / 3$ に抄 訳させていただいた。

韓国は周知のように，明年度より再び獣医学教育を 6 年制に戻すことになっている，李教授には解剖学の教育 に重点を扮きつつ, 獣医学教育全般について言及してい ただいた。この機会にあらためて李教授打よび関係各位 に心から御礼を中しあげる，読者会員に上って，これか らの日本の獣医学教育について示唆に富む内容であると 考え, 日本獣医師会雑誌に掲載を打願いしたところ快諾 していただいた．獣医解剖学会として謝意を表する次第 である。

（山口大 牧田登之）

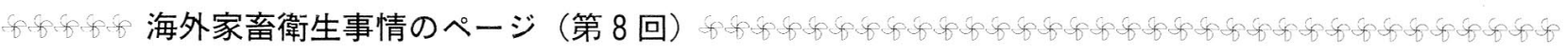

\section{米国に打ける1995 年の狂犬病調査（その3）}

John W. Krebs, Tara W. Strine, Jean S. Smith, Donald L. Noah, Charles E. Rupprecht and James E. Childs

Viral and Rickettsial Zoonoses Branch (Krebs, Smith, Noah, Rupprecht, Childs) and Biometrics Activity (Strine), Division of Viral and Rickettsial Diseases, National Center for Infectious Diseases, Centers for Disease Control and Prevention, Atlanta, GA 30333.

検

狂犬病調查データの評価に当たってはいくつかの要因 を検討しなければならない。この報告で触れられている のは，州，コロンビア特別区，扎よび自治領プエルトリ コの保健当局が研究所で確認し, 疫病予防センターに報 告してきた狂犬病の症例だけである。調査対象にならな かった狂犬病感染動物も少なくなく，これらの動物は検 查されていないことになる。試験材料・提出之検查の于: 法は州によって異なっており，調榃の水準は「王に受動 的」から「幾分能動的」まで幅がある。したがって, 報 告された狂犬病症例は狂犬病流行の大まかな指標にすぎ ず，すべての地域の家畜や野牛動物のウイルス感染の程
度走示すのではない。

1995 年の野生動物狂犬病の報告症例数は 2 年連続の 前年比滅少となった。アアライグマの狂犬病の報告症例は 引き続き1995年も米国の動物狂犬病の報告総数の多数 (50\%超)を占めている。これまで陸生哺乳類に抢ける 狂犬病症例の件数がわずかしかなかったメイン州がアラ イグマ狂犬病が地域的流行となっている州のリストに加 わった（1995 年は101 件). 1995 年にはアライグマの狂 犬病について地域的流行が 18 州とコロンビア特別区で 確認されている. 対象地域から1995 年に報告された狂 犬病症例は，アライグマでは米国全体の 98.9\% (3,920/ 3,964 件), 全動物では全体の $74.4 \%$ (5,860/7,881 件) 